ISSN 1392-3196 / e-ISSN 2335-8947

Zemdirbyste-Agriculture, vol. 102, No. 1 (2015), p. 31-40

DOI 10.13080/z-a.2015.102.004

\title{
Changes in the productivity of wild and cultivated stinging nettle (Urtica dioica $L$.) as influenced by the planting density and crop age
}

\author{
Zofija JANKAUSKIENĖ, Elvyra GRUZDEVIENĖ \\ Upytė Experimental Station, Lithuanian Research Centre for Agriculture and Forestry \\ Linininkų 3, Upytė, Panevėžys distr., Lithuania \\ E-mail: soja@upyte.lzi.lt
}

\begin{abstract}
An interest in the stinging nettle (Urtica dioica L.), as a multi-purpose plant, has been on the increase in many countries throughout Europe and even worldwide recently. The study was conducted at the Upyte Experimental Station of the Lithuanian Research Centre for Agriculture and Forestry in 2010-2012 in which we investigated the productivity of the stinging nettle crop, established at different planting densities and that of nettle crops of different age (the number of cropping years), as well as changes in yielding and morphological parameters in senescent plants. Some data of cultivated nettle were compared to those of wild nettle. The research findings showed that in all experimental years, irrespective of crop age, the productivity per plant was higher at a planting density of $60 \times 100 \mathrm{~cm}$. The green biomass yield generally was higher in the treatments planted at $60 \times 60 \mathrm{~cm}$ density. The mean green above-ground mass yield per plant was going down with crop senescence. The mean absolutely dry above-ground mass yield was higher in 2010 (close to $14 \mathrm{t} \mathrm{ha}^{-1}$ ), while in 2011 and 2012, the yield was much lower $-6.5-7.1 \mathrm{t} \mathrm{ha}^{-1}$. The green above-ground mass yield of wild nettle was lower than that of cultivated nettle and the absolutely dry above-ground mass yield of wild nettle was approximately $2-3$ times lower than that of cultivated nettle. The mean crop density (at harvest) increased over the years of investigation and was higher in an older crop. Starting from the $3^{\text {rd }}$ cropping year, crop density at harvest in the treatment planted at lower density $(60 \times 100 \mathrm{~cm})$ exceeded crop density at the treatments planted at higher density $(60 \times 60 \mathrm{~cm})$. The number of wild nettle stems per $\mathrm{m}^{2}$ was much lower than that of cultivated nettle. The greatest increase $(110-217 \%)$ in the crop density over the vegetation period was found in the plots planted at lower density $(60 \times 100 \mathrm{~cm})$. In an older crop, stinging nettle produced more but shorter stems.
\end{abstract}

Key words: biomass, number of stems, stem diameter, stem length, Urtica dioica.

\section{Introduction}

Flax (Linum usitatissimum L.) and hemp (Cannabis sativa L.) are well-known fibre plants, but the fibres of stinging nettle (Urtica dioica L.) are also used for textile purposes (Hartl, Vogl, 2002). The common stinging nettle has been used by man since the Bronze Age (Whitney, Gibbs, 2006). It is believed that people used wild nettle plants that grew near settlements. The use of bast fibres of nettle was first documented by Nestorius in AD 900 (Vogl, Hartl, 2003). Till the $18^{\text {th }}$ century, stinging nettle was grown in Scandinavia, and possibly, in Scotland (Whitney, Gibbs, 2006).

Stinging nettle (Urtica dioica L.) was cultivated in Central Europe during the $19^{\text {th }}$ century until the Second World War and has a long history as a fibre plant in Germany and Austria (Hartl, Vogl, 2002; Bacci et al., 2007; 2010). During the First and Second World Wars, fibre nettle was promoted as a substitute for cotton as Germany turned to nettles to make army uniforms as a result of cotton shortages. About 500 ha of fibre nettle was cultivated in Germany and Austria in the 1940s and used for textile production after which the crop was no longer produced. Processing facilities for nettles were destroyed during the Second World War and other cheaper fibres were more easily available (Hartl, Vogl, 2002).

German researcher and breeder Bredemann used 170 nettle provenances in over 30 years (19181950) of breeding, from which the most efficient clones were chosen for crossing. Fibre content was increased from about $5 \%$ in wild nettle plants to up to $17 \%$ of stems dry matter in the cultivated species. His criteria for breeding were: frost tolerance, good growth (long and not ramified, straight and stable stems, many leaves and strong tillering) and high fibre content. So developed fibre clones of stinging nettle were first selected in 1959 (Virgilio di et al., 2008). Clone varieties dating back to Bredemann are still maintained at research institutions in Germany (Hartl, Vogl, 2002; Vogl, Hartl, 2003). After 40 years, the plants (30 clones) Bredemann bred during that period were started to be cultivated again at the Institute of Applied Botany, Hamburg, Germany between 1992 and 1995 (Dreyer et al., 1996). 
Recently stinging nettle has become the subject of scientific interest in many countries throughout Europe: Austria, Germany, Finland, United Kingdom, the Netherlands, Italy, Latvia and Lithuania (Bacci et al., 2010; Bisht et al., 2012). The first investigations of stinging nettle in Lithuania gave promising results (Jankauskienè, Gruzdevienè, 2008; 2010; 2013).

Natural fibres have gained renewed interest over the last decade due to their varied uses in textiles, composites, handicrafts, packaging, etc., and consumer demand for environmentally sustainable and traceable processing chains (Bacci et al., 2010).

Stinging nettle is a multi-purpose plant (Jankauskienè, Gruzdeviené, 2008; Bisht at al., 2012; Virgilio di et al., 2014). In the first growing year the plants are too small to harvest for fibre yield, but it is necessary to cut plants to stimulate them to produce more shoots and tillers, therefore it is possible to use cut top part of plants for other valuable purposes. Nettle has a lot of potential applications. Most of them are similar to those of hemp and flax. Potential uses include fibre, protein, medicine, culinary, biomass, oil, repellent and waterproofing. It was suggested in 2000 that stinging nettle is one of the most undervalued economic plants with potential applications in a wide range of uses. Nettle has several medicinal properties: astringent, tonic, anti-asthmatic, diuretic, etc. Across Europe and other countries it is also used for the treatment of gout, dropsy, rheumatism and for weight loss. Nettle roots are commonly used in hair products to treat eczema and dandruff along with helping to stimulate hair growth (Fern, 1997; Bnouham et al., 2003; Gulcin et al., 2004; Chrubasika et al., 2007).

Nettle crop requires low agronomic inputs so is highly feasible for organic farming, as a perennial crop it reduces soil erosion, and being a nitrophilous species it recovers over-fertilized soils (Bacci et al., 2010).

Fertilization with aqueous extracts of stinging nettle could be of great importance in sustainable agricultural practices as positive effects of nettle water on plant growth and development also effects of nettle extracts on insects, such as aphids, have been reported. Nettle extracts showed a repellent activity, especially those obtained from leaves (Camilli et al., 2012).

As stinging nettle is a perennial plant, it can grow for many years, but how long it can be productive, needs to be investigated. Some authors report that the economic life of stinging nettle cultivation is about 6 years, and productive years range from the second to sixth, with a maximum at the third and fourth year (Tavano et al., 2011). Some other sources report that 4 years is the economic limit of growing fibre nettle in the same place while other authors suggest the period of 10-15 years or even longer (Vogl, Hartl, 2003).

The hypotheses that older plants are more productive than younger ones, also that the crop planted at a higher density are more productive for longer years, and that cultivated stinging nettle is more productive than wild one, needs to be verified. The aim of our research was to investigate changes in productivity of stinging nettle crop as influenced by planting densities and crop age (the number of cropping years), and to follow changes in yielding and morphological parameters of senescent stinging nettle crop. It was interesting to get some knowledge about the alterations in crop density during the vegetation season of stinging nettle.
The first results on the productivity of cultivated stinging nettle crop have been already published (Jankauskienè, Gruzdevienè, 2008; 2010; 2013) but have not been compared to those of wild stinging nettle.

\section{Materials and methods}

Experiments were conducted at the Upyte

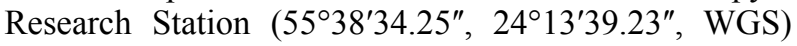
of the Lithuanian Research Centre for Agriculture and Forestry. The soil of the experimental site is an EutriEndohypogleyic Cambisol, CMg-n-w-eu(Buivydaite etal., 2001 ), with a $\mathrm{pH}_{\mathrm{KC} 1}$ level of 6.7-7.7 (potentiometrically), humus concentration - 1.89-2.33\% (ISO 10694:1995), content of available phosphorus $\left(\mathrm{P}_{2} \mathrm{O}_{5}\right)$ in the soil plough layer was between 137 and $245 \mathrm{mg} \mathrm{kg}^{-1}$, the content of available potassium $\left(\mathrm{K}_{2} \mathrm{O}\right)-122-152 \mathrm{mg} \mathrm{kg}^{-1}$ (determined in A-L extraction). The trial plots were established in 2008 and 2009. The plants of stinging nettle (clones obtained from the Netherlands) were cut in pieces and vegetatively multiplied (Jankauskienè, Gruzdeviené, 2008; 2010). The $1^{\text {st }}$ treatment (crop density $60 \mathrm{~cm}$ between the plants in the row $\times 60 \mathrm{~cm}$ inter-row spacing) was established in May 2008. Full care of plants was carried out (dead plants were replaced by live ones; cultivation of interrow spaces was carried out manually). In 2009 , the $2^{\text {nd }}$ and $3^{\text {rd }}$ treatments were set up - the crop of $60 \times 60$ and $60 \times 100 \mathrm{~cm}$, respectively. As a result, crops of different planting density $(60 \times 60$ and $60 \times 100 \mathrm{~cm})$ and age were obtained.

Thus starting in 2010, we already had a crop of the $3^{\text {rd }}$ cropping year (established in 2008) $60 \times 60 \mathrm{~cm}$, also the crop of the $2^{\text {nd }}$ year (established in 2009) $60 \times$ $60 \mathrm{~cm}$, also a crop of the $2^{\text {nd }}$ year (established in 2009), $60 \times 100 \mathrm{~cm}$. Later on, the denomination of treatments included the year of cropping and planting density.

Stinging nettle crop was fertilised by $\mathrm{N}: \mathrm{P}: \mathrm{K}$ 16:16:16 at a rate of $200 \mathrm{~kg} \mathrm{ha}^{-1}$ in the first half of May.

Wild nettle plants for investigation were sampled from the Lithuanian population of stinging nettle (Urtica dioica L.) growing at the same habitat for many years.

Observations. In 2010, the first green shoots of cultivated stinging nettle were found on the $3^{\text {rd }}$ of April, but the weather was still too cold for the plants to thrive. Part of stinging nettle crop was flooded at the end of March, which had a negative influence on the crop, apparent even a few years later - the number of stinging nettle shoots in the damaged places decreased, and the weeds occupied vacant places. Stinging nettle was harvested on $30^{\text {th }}$ of August. In 2011, already in the middle of March small $(0.5 \mathrm{~cm})$ violet shoots of stinging nettle were noticed after the snow had melted. Nevertheless, meteorological conditions still were not suitable for growing. In the beginning of April, the shoots of stinging nettle were already $3 \mathrm{~cm}$ in height, the vegetation started early. Stinging nettle was thriving well; it was harvested on the $12^{\text {th }}$ of September. The spring came late in 2012. In the beginning of May stinging nettle started to grow. Despite the quite great amount of precipitation, the plants were not very luxuriant. Stinging nettle was harvested on the $4^{\text {th }}$ of September.

Assessments. The crop density was assessed in the spring, when stinging nettle plants came into leaf (in the beginning of June) and at harvesting. In the established crop, before harvesting the entire crop, all 
stems of stinging nettle plants in the area of $4 \mathrm{~m}^{2}(2 \times$ $2 \mathrm{~m}$ ) (in tree replications) were cut manually (leaving the stubble of $15 \mathrm{~cm}$ for sprouting) for evaluation (9 plants from the plots planted at $60 \times 60 \mathrm{~cm}$ density, and 6 plants from the plots planted at $60 \times 100 \mathrm{~cm}$ density). Then the data were re-calculated for $1 \mathrm{~m}^{-2}, 1 \mathrm{ha}^{-1}$ and for 1 plant. In 2010-2012, the inter-row spaces were already not visible because of increased density of the crop, but in 2010, some inter-row space still was observed in the crop planted at $60 \times 100 \mathrm{~cm}$ density. The weight of green above-ground biomass (stems, leaves and inflorescences), its moisture content, absolutely dry biomass, number of stems per plant, length of sawn-off stems, their diameter as well as dynamics of plant density were assessed for each trial plot. The yield of green and dry biomass (over-ground mass) was assessed after sawing-off and weighting all cut stems of each plot in the area of $4 \mathrm{~m}^{2}$. One stem per plot was cut into small pieces and the sample for moisture content determination was taken directly in the field. All stems in the record plot were counted (crop density) and measured. The biometric indices - stem height (total length of sawnoff stinging nettle stem) and diameter in the middle of the stem - were measured at harvesting time. In 2010-2012, the investigated parameters of cultivated stinging nettle plants were compared between treatments and some of them to those of wild stinging nettle.

Meteorological conditions. The meteorological conditions were diverse during the experimental years, but all vegetation seasons were abundant in rainfall which differed only between hemp growing stages. Thermal and irrigation conditions during the vegetation season could be described by one of the most informative agrometeorological indicators - Selianinov's hydrothermal coefficient HTC $=\Sigma \mathrm{p} / 0.1 \Sigma \mathrm{t}$, where: $\Sigma \mathrm{p}$ - total precipitation $(\mathrm{mm})$ during the given period, the temperature of which is above $10^{\circ} \mathrm{C} ; \Sigma \mathrm{t}$ - sum of active temperatures $\left({ }^{\circ} \mathrm{C}\right)$ of the same period. If HTC $>1.6-$ the irrigation is excessive, $\mathrm{HTC}=1.0 \ldots 1.5-$ optimal irrigation, $\mathrm{HTC}=0.9 \ldots 0.8-$ weak drought, $\mathrm{HTC}=0.7$ ... 0.6 - moderate drought (arid), HTC $=0.5 \ldots 0.4-$ heavy drought, HTC $<0.4$ - very heavy drought (Dirsè, Taparauskienè, 2010).

According to the data presented in Figure, we can see that in 2010 it was wet enough in May. In the first ten-day period of June, it was droughty, but in the second ten-day period the irrigation was excessive, then it was close to the normal for the third ten-day period. The weather in July was warm, and the rainfall was sufficient for stinging nettle growing. The precipitation in July third ten-day period and in August (except for the first ten-day period) was again abundant. In 2011, the hydrothermal coefficient showed favourable meteorological conditions for stinging nettle growing in the middle of May. Later on (in June) the moderate drought was in the field, but the rest of the stinging nettle vegetation period had plenty of rainfall. The irrigation was excessive in the first tenday period of July, second ten-day period of July, first and second ten-day period of August and second ten-day period of September. The weather was warm and the precipitation was especially abundant in July and August. In 2012, the beginning of stinging nettle vegetation was quite abundant in precipitation (May, first and third tenday period of June). In the first and third ten-day periods of July the irrigation was close to normal. Irrigation was excessive again in the beginning of August and middle of September.

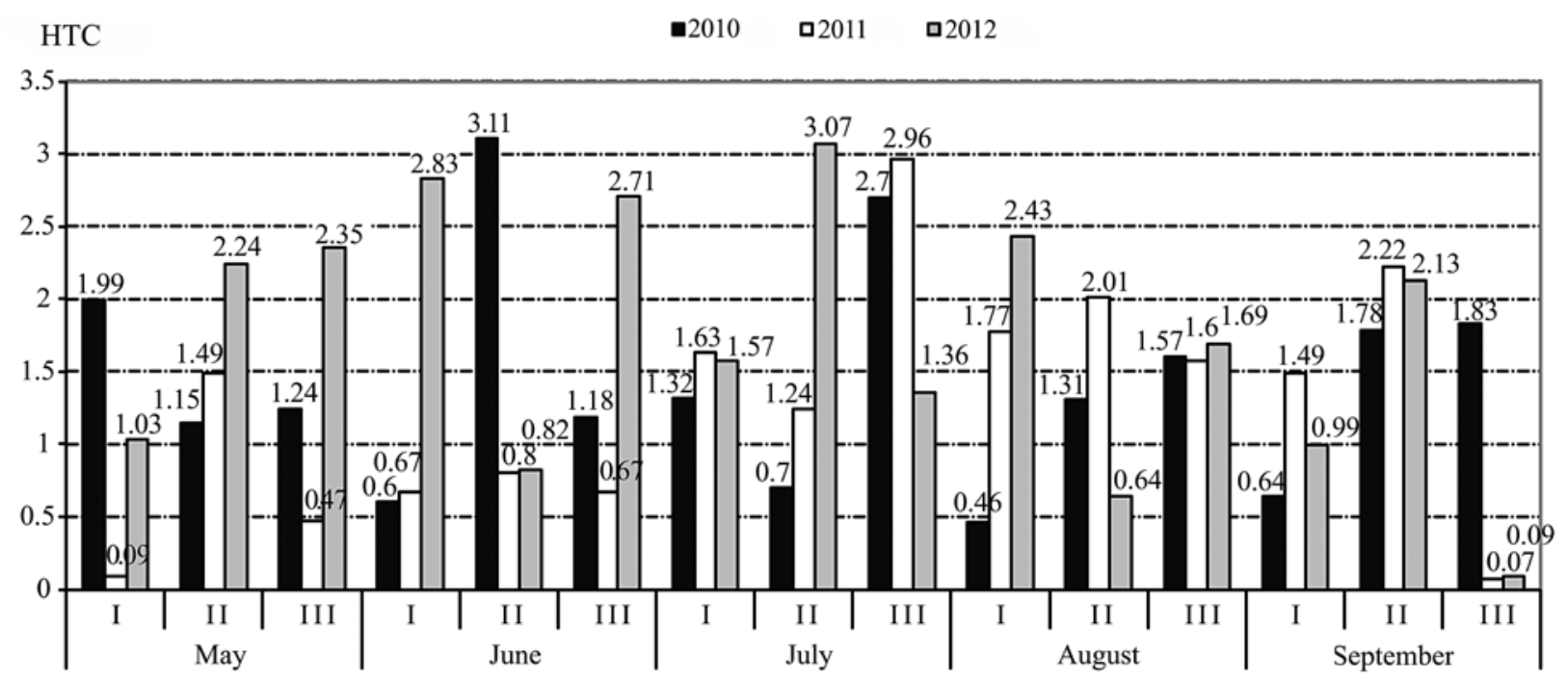

Figure. Hydrothermal coefficient in 2010-2012, Upyte, Panevėžys district

Statistical analysis. The statistical analyses were made using ANOVA software from the statistical data processing package SELEKCIJA (Tarakanovas, Raudonius, 2003). The data were processed twice (where the data of stinging nettle were available): compared to the mean of the trial (of three tested treatments), as well as to the data of stinging nettle considering this treatment as a control. Significant differences at 0.05 probability (at least) level are marked as * over all text and tables of the article.

\section{Results and discussion}

Stinging nettle is a perennial plant, in each year producing new shoots from rhizomes and stolons. After planting, a plant produces a lot of stems. In the established treatments we knew the exact number of plants after planting $\left(9\right.$ plants $4 \mathrm{~m}^{-2}$, or 2.25 plants $\mathrm{m}^{-2}$ at $60 \times 60 \mathrm{~cm}$ treatments, and 6 plants $4 \mathrm{~m}^{-2}$, or 1.5 plants $\mathrm{m}^{-2}$ in $60 \times 100 \mathrm{~cm}$ treatment). However, we did not know the number of wild nettle because in order to count them 
we would need to pull them out and destroy the crop, therefore we could count only the number of stems per unit area. Thus, some data of wild nettle in the tables are missing. In all tables, in the left column part, the data of cultivated nettle are compared, and in the right column part, the data of cultivated nettle are compared to the data of wild nettle.

The data in Table 1 show that mean green above-ground mass yield per plant was going down with crop senescence $\left(1.41,1.29\right.$ and $0.96 \mathrm{~kg}_{\text {plant }}{ }^{-1}$ in 2010 , 2011 and 2012, respectively). But the weather conditions also had the effect on these results as the comparison of the yearly data of the same crop density $(60 \times 60 \mathrm{~cm})$ of different cropping year showed varying results. Over all experimental years, irrespective of crop age, the productivity per plant was higher at a crop density of 60 $\times 100 \mathrm{~cm}$. But when analyzing calculated yield data, the same tendency of decrease of mean green above-ground mass with crop senescence could be noted; just the yield of green mass was not always the highest at a planting density of $60 \times 100 \mathrm{~cm}$. Thus we can state that since the $4^{\text {th }}-5^{\text {th }}$ cropping year the green above-ground biomass yield of stinging nettle is going down, but probably it could be maintained at a higher level by maintaining higher mineral nutrition.

In our previous trials, in 2009, the weight of green over-ground mass (stems, leaves, inflorescences) was close to $38 \mathrm{t} \mathrm{ha}^{-1}$ from the crop of the $2^{\text {nd }}$ year, $60 \times$ 60 , and more than $20 \mathrm{t} \mathrm{ha}^{-1}$ from the crop of the $1^{\text {st }}$ year (Jankauskienè, Gruzdevienè, 2010). Lower yields (18.0$\left.31.3 \mathrm{t} \mathrm{ha}^{-1}\right)$ of green over-ground mass were obtained in the crop over 2010-2012 (Table 1). The green biomass yield was generally higher in the treatments planted at $60 \times 60 \mathrm{~cm}$ density (except for the year 2011), bur the differences were not significant.

The green above-ground mass yield of wild nettle was lower than that of cultivated nettle, showing the advantage of cultivated nettle over wild nettle. Moisture content in stinging nettle plants at harvest time differed between the experimental years. It could be influenced by the weather conditions before/at harvesting. Moisture content in cultivated stinging nettle plants was much lower in 2010 and differed significantly from that of stinging nettle.

Table 1. The green above-ground mass and its moisture content at stinging nettle harvesting

Upytė Experimental Station, 2010-2012

\begin{tabular}{|c|c|c|c|c|c|c|}
\hline \multirow[b]{2}{*}{ Treatments } & \multicolumn{2}{|c|}{$\begin{array}{l}\text { Of } 1 \text { plant } \\
\text { kg plant }^{-1}\end{array}$} & \multicolumn{2}{|c|}{$\begin{array}{l}\text { Of all plants per } 1 \text { ha } \\
\qquad \mathrm{kg} \mathrm{ha}^{-1}\end{array}$} & \multicolumn{2}{|c|}{$\begin{array}{c}\text { Moisture content } \\
\%\end{array}$} \\
\hline & $\begin{array}{c}\text { cultivated } \\
\text { nettle }\end{array}$ & $\begin{array}{c}\text { wild and } \\
\text { cultivated } \\
\text { nettle }\end{array}$ & $\begin{array}{l}\text { cultivated } \\
\text { nettle }\end{array}$ & $\begin{array}{c}\text { wild and } \\
\text { cultivated } \\
\text { nettle }\end{array}$ & $\begin{array}{l}\text { cultivated } \\
\text { nettle }\end{array}$ & $\begin{array}{c}\text { wild and } \\
\text { cultivated } \\
\text { nettle }\end{array}$ \\
\hline \multicolumn{7}{|c|}{2010} \\
\hline Wild nettle & - & - & - & 18840 & - & 66.3 \\
\hline Cultivated nettle, $3^{\text {rd }}$ year, $60 \times 60 \mathrm{~cm}$ & 1.12 & - & 25279 & 25279 & $45.0 *$ & $45.0^{*}$ \\
\hline Cultivated nettle, $2^{\text {nd }}$ year, $60 \times 60 \mathrm{~cm}$ & 1.39 & - & 31258 & $31258^{*}$ & $52.5^{*}$ & $52.5^{*}$ \\
\hline Cultivated nettle, $2^{\text {nd }}$ year, $60 \times 100 \mathrm{~cm}$ & 1.72 & - & 25738 & 25738 & 47.1 & $47.1 *$ \\
\hline Average & 1.41 & - & 27425 & 25278 & 48.21 & 52.8 \\
\hline \multicolumn{7}{|c|}{2011} \\
\hline Wild nettle & - & - & - & 7140 & - & 70.9 \\
\hline Cultivated nettle, $4^{\text {th }}$ year, $60 \times 60 \mathrm{~cm}$ & 1.01 & - & 22800 & $22800 *$ & 70.5 & 70.5 \\
\hline Cultivated nettle, $3^{\text {rd }}$ year, $60 \times 60 \mathrm{~cm}$ & $0.83 *$ & - & 18763 & 18763 & 70.1 & 70.1 \\
\hline Cultivated nettle, $3^{\text {rd }}$ year, $60 \times 100 \mathrm{~cm}$ & $2.02 *$ & - & 30275 & $30275^{*}$ & 70.2 & 70.2 \\
\hline Average & 1.29 & - & 23946 & 19744 & 70.27 & 70.43 \\
\hline \multicolumn{7}{|c|}{2012} \\
\hline Wild nettle & - & - & - & 11220 & - & 69.0 \\
\hline Cultivated nettle, $5^{\text {th }}$ year, $60 \times 60 \mathrm{~cm}$ & 0.85 & - & 19129 & 19129 & $68.7 *$ & 68.7 \\
\hline Cultivated nettle, $4^{\text {th }}$ year, $60 \times 60 \mathrm{~cm}$ & 0.82 & - & 18529 & 18529 & $61.4 *$ & $61.4^{*}$ \\
\hline Cultivated nettle, $4^{\text {th }}$ year, $60 \times 100 \mathrm{~cm}$ & 1.2 & - & 17988 & 17988 & 65.3 & 65.3 \\
\hline Average & 0.96 & - & 18549 & 16716 & 65.11 & 66.09 \\
\hline
\end{tabular}

* - significant at 0.05 probability level

Data of the absolutely dry above-ground mass per plant differed between the years (Table 2). The mean data were similar in 2011 and 2012, but much higher yield was obtained in 2010 (in younger crop). The absolutely dry above-ground mass per plant was the highest at a planting density of $60 \times 100 \mathrm{~cm}$. The mean absolutely dry above-ground mass yield was much higher in 2010 - close to $14 \mathrm{t} \mathrm{ha}^{-1}$, while in 2011 and 2012, the yield was much lower - 6.5-7.1 $\mathrm{t} \mathrm{ha}^{-1}$. Investigations in other countries showed that the nettle's dry stems matter can vary from 2.3-9.7 $\mathrm{t} \mathrm{ha}^{-1}$ (Vogl, Hartl, 2003). The dry stem yield of 2.66 to $5.52 \mathrm{t} \mathrm{ha}^{-1}$ was obtained even without mineral fertilisation (Schmidtke et al., 1998; Kohler et al., 1999). When growing stinging nettle clones of high productivity (Austrian or German), a yield of 6-8 $\mathrm{tha}^{-1}$ of dry matter of straw could be produced (Nebel et al., 2002). Investigation of stinging nettle in Italy in 20062007 showed that clones of German origin produced stem dry matter averaging $1542 \mathrm{~g} \mathrm{~m}^{-2}$, i.e. $15.4 \mathrm{t} \mathrm{ha}^{-1}$ (Bacci et al., 2007).

Our data show that the absolutely dry aboveground mass yield of wild nettle was approximately 2-3 times lower than that of cultivated nettle (significant differences were found in 2010 and 2012). 
Table 2. The absolutely dry above-ground mass at stinging nettle harvesting

Upyte Experimental Station, 2010-2012

\begin{tabular}{|c|c|c|c|c|}
\hline \multirow[b]{2}{*}{ Treatments } & \multicolumn{2}{|c|}{ Of 1 plant, $\mathrm{kg}_{\text {plant }}{ }^{-1}$} & \multicolumn{2}{|c|}{ Of all plants per $1 \mathrm{ha}, \mathrm{kg} \mathrm{ha}^{-1}$} \\
\hline & cultivated nettle & $\begin{array}{l}\text { wild and cultivated } \\
\text { nettle }\end{array}$ & cultivated nettle & $\begin{array}{l}\text { wild and cultivated } \\
\text { nettle }\end{array}$ \\
\hline \multicolumn{5}{|c|}{2010} \\
\hline Wild nettle & - & - & - & 6351 \\
\hline Cultivated nettle, $3^{\text {rd }}$ year, $60 \times 60 \mathrm{~cm}$ & 0.62 & - & 13891 & $13891 *$ \\
\hline Cultivated nettle, $2^{\text {nd }}$ year, $60 \times 60 \mathrm{~cm}$ & 0.66 & - & 14847 & $14847 *$ \\
\hline Cultivated nettle, $2^{\text {nd }}$ year, $60 \times 100 \mathrm{~cm}$ & 0.91 & - & 13615 & $13615^{*}$ \\
\hline Average & 0.73 & - & 14118 & 12176 \\
\hline \multicolumn{5}{|c|}{2011} \\
\hline Wild nettle & - & - & - & 2079 \\
\hline Cultivated nettle, $4^{\text {th }}$ year, $60 \times 60 \mathrm{~cm}$ & 0.30 & - & 6832 & $6832 *$ \\
\hline Cultivated nettle, $3^{\text {rd }}$ year, $60 \times 60 \mathrm{~cm}$ & 0.25 & - & 5585 & 5585 \\
\hline Cultivated nettle, $3^{\text {rd }}$ year, $60 \times 100 \mathrm{~cm}$ & $0.60 *$ & - & 9036 & $9036^{*}$ \\
\hline Average & 0.38 & - & 7151 & 5883 \\
\hline \multicolumn{5}{|c|}{2012} \\
\hline Wild nettle & - & - & - & 3404 \\
\hline Cultivated nettle, $5^{\text {th }}$ year, $60 \times 60 \mathrm{~cm}$ & 0.27 & - & 6112 & 6112 \\
\hline Cultivated nettle, $4^{\text {th }}$ year, $60 \times 60 \mathrm{~cm}$ & 0.32 & - & 7150 & 7150 \\
\hline Cultivated nettle, $4^{\text {th }}$ year, $60 \times 100 \mathrm{~cm}$ & 0.42 & - & 6235 & 6235 \\
\hline Average & 0.34 & - & 6499 & 5725 \\
\hline
\end{tabular}

* - significant at 0.05 probability level

As the stinging nettle is a perennial plant, the stems that emerge in spring and grow during the vegetation season do not survive the winter. Since 2010, in our trials we started counting crop density twice - in spring and in autumn.

Klimešova (1994) have reported that floods significantly reduce the survival of young Urtica plants, and reduce the biomass of older plants without killing them. Taylor (2009) states that Urtica dioica ssp. dioica cannot survive flooding of its roots and rhizomes for long periods, as it does not have any special adaptation to anoxic conditions. This was also confirmed by our trials. The inundation on the part of stinging nettle crop was recorded at the end of March, 2010, and it had a negative influence on the crop, detectable even a few years later - the amount of stinging nettle shoots decreased, and the weeds occupied vacant places. In 2010, after the inundation, the mean number of shoots per plant in the spring was the least when compared to other two years of investigation and to the data from previous trials (Jankauskienè, Gruzdevienè, 2010). In 2011, the mean number of shoots per plant was quite similar, but in spring 2012, a sharp increase in the shoot number per plant in treatment $60 \times 100$ was noticed, and the mean shoot number was twice as high there (Table 3). Also we can state, that older plants produced more shoots.

Table 3. Number of stems (crop density) when stinging nettle crop came into leaf Upyte Experimental Station, 2010-2012

\begin{tabular}{|c|c|c|c|c|c|c|}
\hline \multirow[b]{2}{*}{ Treatments } & \multicolumn{2}{|c|}{$\begin{array}{l}\text { Of } 1 \text { established plant, } \\
\text { stems plant }^{-1}\end{array}$} & \multicolumn{2}{|c|}{$\begin{array}{l}\text { Of all plants per } \mathrm{m}^{2}, \\
\text { stems } \mathrm{m}^{-2}\end{array}$} & \multicolumn{2}{|c|}{$\begin{array}{l}\text { Of all plants per ha, } \\
\text { stems ha-1 }\end{array}$} \\
\hline & $\begin{array}{l}\text { cultivated } \\
\text { nettle }\end{array}$ & $\begin{array}{l}\text { wild and } \\
\text { cultivated } \\
\text { nettle }\end{array}$ & $\begin{array}{l}\text { cultivated } \\
\text { nettle }\end{array}$ & $\begin{array}{l}\text { wild and } \\
\text { cultivated } \\
\text { nettle }\end{array}$ & $\begin{array}{l}\text { cultivated } \\
\text { nettle }\end{array}$ & $\begin{array}{c}\text { wild and } \\
\text { cultivated } \\
\text { nettle }\end{array}$ \\
\hline \multicolumn{7}{|c|}{$2010(03062010)$} \\
\hline Wild nettle & - & - & - & - & - & - \\
\hline Cultivated nettle, $3^{\text {rd }}$ year, $60 \times 60 \mathrm{~cm}$ & $25.7 *$ & - & $57.9 *$ & - & $579167^{*}$ & - \\
\hline Cultivated nettle, $2^{\text {nd }}$ year, $60 \times 60 \mathrm{~cm}$ & 20.2 & - & 45.4 & - & 454167 & - \\
\hline Cultivated nettle, $2^{\text {nd }}$ year, $60 \times 100 \mathrm{~cm}$ & $15.8 *$ & - & $23.7 *$ & - & $236667^{*}$ & - \\
\hline Average & 20.57 & - & 42.33 & - & 423333 & - \\
\hline \multicolumn{7}{|c|}{$2011(06062011)$} \\
\hline Wild nettle & - & - & - & - & - & - \\
\hline Cultivated nettle, $4^{\text {th }}$ year, $60 \times 60 \mathrm{~cm}$ & 25.0 & - & 56.3 & - & 562500 & - \\
\hline Cultivated nettle, $3^{\text {rd }}$ year, $60 \times 60 \mathrm{~cm}$ & 20.5 & - & 46.1 & - & 460833 & - \\
\hline Cultivated nettle, $3^{\text {rd }}$ year, $60 \times 100 \mathrm{~cm}$ & 25.7 & - & 38.6 & - & 385833 & - \\
\hline Average & 23.73 & - & 46.97 & - & 469722 & - \\
\hline \multicolumn{7}{|c|}{$2012(01062012)$} \\
\hline Wild nettle & - & - & - & - & - & - \\
\hline Cultivated nettle, $5^{\text {th }}$ year, $60 \times 60 \mathrm{~cm}$ & 25.7 & - & 57.9 & - & 579167 & - \\
\hline Cultivated nettle, $4^{\text {th }}$ year, $60 \times 60 \mathrm{~cm}$ & 37.2 & - & 83.7 & - & 836667 & - \\
\hline Cultivated nettle, $4^{\text {th }}$ year, $60 \times 100 \mathrm{~cm}$ & $60.4^{*}$ & - & 90.6 & - & 905833 & - \\
\hline Average & 41.1 & - & 77.39 & - & 773889 & - \\
\hline
\end{tabular}

* - significant at 0.05 probability level 
In 2010 , older crop $\left(3^{\text {rd }}\right.$ year, $\left.60 \times 60\right)$ produced more shoots than younger crop $\left(2^{\text {nd }}\right.$ year, $\left.60 \times 60\right)$, and plants in a denser crop $\left(2^{\text {nd }}\right.$ year, $\left.60 \times 60\right)$ produced more shoots than plants in thinner crop crop (2nd year, $60 \times$ $100)$. In the spring 2011 , crop density was again lower (Table 3) than that in the autumn 2010 (Table 4). In the spring 2011, the number of stems per plant was rather similar in all treatments (20.5-25.7), nevertheless, the number of stems per $1 \mathrm{~m}^{2}$ was higher in the mature crop $\left(4^{\text {th }}\right.$ year, $\left.60 \times 60\right)$ than that in the younger crop $\left(3^{\text {rd }}\right.$ year, $60 \times 60$ ), and higher in the plots of the crop of higher planting density $(60 \times 60 \mathrm{~cm})$ than that in the plots of lower planting density $(60 \times 100 \mathrm{~cm})$. The differences were not significant. In the spring 2012, crop density again was lower than that in the autumn 2011, but it was especially higher than that in the spring 2011 in the plots of different planting density $(60 \times 60$ and $60 \times 100 \mathrm{~cm})$. The number of stems per plant in the beginning of vegetation was significantly higher in the plots of lower planting density $(60 \times 100 \mathrm{~cm})$.

In 2010 and 2011, the crop density at the beginning of vegetation was higher in the crop of higher planting density $(60 \times 60 \mathrm{~cm})$, and only in 2012 , it became greater in the crop of lower planting density $(60$ $\times 100 \mathrm{~cm}$ ). In the last column of the presented tables we can see what huge number of stems could be produced per ha. The mean crop density (at harvest) increased over the years of investigation and was higher in older crop (Table 4). Starting only from the $3^{\text {rd }}$ cropping year, crop density at harvest in the treatment of lower planting density $(60 \times 100 \mathrm{~cm})$ exceeded crop density in the treatments of higher planting density $(60 \times 60 \mathrm{~cm})$.

During the vegetation season in 2010, the number of stems per plant increased, but the differences were not significant (Tables 4-5). The greatest increase was found in the plots of lower planting density $(60 \times$ $100 \mathrm{~cm}$ ) - from 16 to 37 stems per plant per vegetation season. In the plots with planting density $60 \times 60 \mathrm{~cm}$, increase of stem number per plant was rather similar -
13.9-16.0 stems per plant per vegetation season, and was not dependent on crop maturity ( $3^{\text {rd }}$ or $2^{\text {nd }}$ cropping year). In the trials of Hartl and Vogl (2002), in the $3^{\text {rd }}$ cropping year the number of stems per plot (planting density was $60 \times 100 \mathrm{~cm}$ ) was twice as high as in the $2^{\text {nd }}$ cultivation year. In our trials the increase was very similar and even bigger - 2.22 time more. Crop density in the nettle trials in Italy was found to be much higher - it was close to 132 stems $\mathrm{m}^{-2}$ of the $2^{\text {nd }}$ cropping year (planting density $50 \times$ $75 \mathrm{~cm}$ ) (Bacci et al., 2009).

The vegetation season in 2011 was favourable for stinging nettle whose crop density increased more than twice since the beginning of vegetation (Tables 4-5). The differences between treatments were not significant, but crop density was over 100 stems $\mathrm{m}^{-2}$. When compared older and younger crop $(60 \times 60 \mathrm{~cm})$, mature crop showed better results. When compared crops of different planting density $(60 \times 60$ and $60 \times 100 \mathrm{~cm})$, the crop of the lower planting density showed better results. The number of stems per plant was significantly higher in the plots of lower planting density $(60 \times 100 \mathrm{~cm})-82.2$ stems per plant.

At harvesting, crop density in 2012 was rather similar to that in 2011. It could be that the optimal crop density is already achieved, and it will not increase any more in more mature crop in following years. Crop density was approximately the same in more mature and in younger crop $(60 \times 60 \mathrm{~cm})-112-115$ plants $\mathrm{m}^{-2}$, and higher in the plots of lower planting density crop $(60 \times$ $100 \mathrm{~cm})-136.4$ stems per $\mathrm{m}^{2}$. Crop density during the vegetation season in 2012 increased, but not as greatly as in 2011. In 2012 as well as in 2011, the highest number of stems per plant was significantly higher in the plots of lower planting density crop $(60 \times 100 \mathrm{~cm})$ - even 90.9 stems per plant. Comparison of calculated data of cultivated to wild stinging nettle show that number of stems of wild nettle was much lesser then that of cultivated nettle, just differences not always were significant (Table 4).

Table 4. Number of stems (crop density) at stinging nettle harvesting

Upyte Experimental Station, 2010-2012

\begin{tabular}{|c|c|c|c|c|c|c|}
\hline \multirow[b]{2}{*}{ Treatments } & \multicolumn{2}{|c|}{$\begin{array}{l}\text { Of } 1 \text { established plant, } \\
\text { stems plant }^{-1}\end{array}$} & \multicolumn{2}{|c|}{$\begin{array}{l}\text { Of all plants per } \mathrm{m}^{2}, \\
\text { stems } \mathrm{m}^{-2}\end{array}$} & \multicolumn{2}{|c|}{$\begin{array}{l}\text { Of all plants per ha, } \\
\text { stems ha }\end{array}$} \\
\hline & $\begin{array}{l}\text { cultivated } \\
\text { nettle }\end{array}$ & $\begin{array}{c}\text { wild and } \\
\text { cultivated } \\
\text { nettle }\end{array}$ & $\begin{array}{l}\text { cultivated } \\
\text { nettle }\end{array}$ & $\begin{array}{c}\text { wild and } \\
\text { cultivated } \\
\text { nettle }\end{array}$ & $\begin{array}{l}\text { cultivated } \\
\text { nettle }\end{array}$ & $\begin{array}{c}\text { wild and } \\
\text { cultivated } \\
\text { nettle }\end{array}$ \\
\hline \multicolumn{7}{|c|}{2010} \\
\hline Wild nettle & - & - & - & 47.3 & - & 506667 \\
\hline Cultivated nettle, $3^{\text {rd }}$ year, $60 \times 60 \mathrm{~cm}$ & 39.6 & - & 89.1 & $89.1 *$ & 890833 & 890833 \\
\hline Cultivated nettle, $2^{\text {nd }}$ year, $60 \times 60 \mathrm{~cm}$ & 36.2 & - & 81.5 & 81.5 & 815000 & 815000 \\
\hline Cultivated nettle, $2^{\text {nd }}$ year, $60 \times 100 \mathrm{~cm}$ & 36.9 & - & 55.4 & 55.4 & 554167 & 554167 \\
\hline Average & 37.59 & - & 75.33 & 68.33 & 753333 & 691337 \\
\hline \multicolumn{7}{|c|}{2011} \\
\hline Wild nettle & - & - & - & 60.0 & - & 600000 \\
\hline Cultivated nettle, $4^{\text {th }}$ year, $60 \times 60 \mathrm{~cm}$ & 54.2 & - & 121.8 & $121.8 *$ & 1218333 & $1218333^{*}$ \\
\hline Cultivated nettle, $3^{\text {rd }}$ year, $60 \times 60 \mathrm{~cm}$ & 47.4 & - & 106.7 & 106.7 & 1066667 & 1066667 \\
\hline Cultivated nettle, $3^{\text {rd }}$ year, $60 \times 100 \mathrm{~cm}$ & $82.2 *$ & - & 123.3 & $123.3 *$ & 1233333 & $1233333^{*}$ \\
\hline Average & 61.26 & - & 117.28 & 102.96 & 1172778 & 1029583 \\
\hline \multicolumn{7}{|c|}{2012} \\
\hline Wild nettle & - & - & - & 71.7 & - & 716667 \\
\hline Cultivated nettle, $5^{\text {th }}$ year, $60 \times 60 \mathrm{~cm}$ & 51.0 & - & 114.7 & 114.7 & 1146667 & 1146667 \\
\hline Cultivated nettle, $4^{\text {th }}$ year, $60 \times 60 \mathrm{~cm}$ & 49.9 & - & 112.2 & 112.2 & 1121667 & 1121667 \\
\hline Cultivated nettle, $4^{\text {th }}$ year, $60 \times 100 \mathrm{~cm}$ & 90.9 & - & 136.4 & 136.4 & 1364167 & 1364167 \\
\hline Average & 63.92 & - & 121.08 & 108.73 & 1210833 & 1087292 \\
\hline
\end{tabular}

\footnotetext{
* - significant at 0.05 probability level
} 
Hara and Šrůtek (1995) from Czech Republic state that in the stands of Urtica dioica there was a large decrease in shoot density resulting in a survival rate at the end of the vegetation season of about $30 \%$. In our trials we found only an increase in the shoot number during the vegetation period (Table 5), this might have resulted from the fact that our stinging nettle crop was not as dense as it was in the trials in Czech Republic (over 400 600 shoots per $\mathrm{m}^{2}$ in the spring). In our trials the greatest (110-217\%) increase was always noted in the treatment of lower planting density $(60 \times 100 \mathrm{~cm})$.

Table 5. The stems augment in stinging nettle crop from coming into leaf till harvest Upyte Experimental Station, 2010-2012

\begin{tabular}{|c|c|c|c|c|}
\hline Treatments & $\begin{array}{l}\text { Of } 1 \text { established plant, } \\
\text { stems plant }^{-1}\end{array}$ & $\begin{array}{l}\text { Of all plants per } \mathrm{m}^{2}, \\
\text { stems } \mathrm{m}^{-2}\end{array}$ & $\begin{array}{l}\text { Of all plants per ha, } \\
\text { stems ha } \text { ha }^{-1}\end{array}$ & $\begin{array}{c}\text { Increase } \\
\%\end{array}$ \\
\hline \multicolumn{5}{|c|}{2010} \\
\hline Cultivated nettle, $3^{\text {rd }}$ year, $60 \times 60 \mathrm{~cm}$ & 13.9 & 31.17 & 311667 & 54.7 \\
\hline Cultivated nettle, $2^{\text {nd }}$ year, $60 \times 60 \mathrm{~cm}$ & 16.0 & 36.08 & 360833 & 78.6 \\
\hline Cultivated nettle, $2^{\text {nd }}$ year, $60 \times 100 \mathrm{~cm}$ & 21.2 & 31.75 & 317500 & 133.2 \\
\hline Average & 17.02 & 33.00 & 330000 & 88.82 \\
\hline \multicolumn{5}{|c|}{2011} \\
\hline Cultivated nettle, $4^{\text {th }}$ year, $60 \times 60 \mathrm{~cm}$ & 29.2 & 65.6 & 655833 & 135.0 \\
\hline Cultivated nettle, $3^{\text {rd }}$ year, $60 \times 60 \mathrm{~cm}$ & 26.9 & 60.6 & 605833 & 139.7 \\
\hline Cultivated nettle, $3^{\text {rd }}$ year, $60 \times 100 \mathrm{~cm}$ & 56.5 & 84.8 & 847500 & 217.3 \\
\hline Average & 37.52 & 70.31 & 703055 & 164.00 \\
\hline \multicolumn{5}{|c|}{2012} \\
\hline Cultivated nettle, $5^{\text {th }}$ year, $60 \times 60 \mathrm{~cm}$ & 15.7 & 35.3 & 352500 & 51.5 \\
\hline Cultivated nettle, $4^{\text {th }}$ year, $60 \times 60 \mathrm{~cm}$ & 12.7 & 28.5 & 285000 & 34.8 \\
\hline Cultivated nettle, $4^{\text {th }}$ year, $60 \times 100 \mathrm{~cm}$ & $46.9 *$ & 70.3 & 703333 & 110.1 \\
\hline Average & 25.07 & 44.69 & 446944 & 65.44 \\
\hline
\end{tabular}

* - significant at 0.05 probability level

The number of stems does not always reflect actual situation, because the length and the diameter of the stems in the crop can be very different. Dreyer et al. (1996) suggest that the stubble of at least $10 \mathrm{~cm}$ should be left for better plant survival after stinging nettle harvest. From the first year of the established crop the stubble of $15 \mathrm{~cm}$ was left (to stimulate the branching of plants), and later on, we continued harvesting at the same stubble level each year. The presented stem length is the length without the stubble height (Table 6). The mean data show that stinging nettle of older crop produces shorter stems. Especially high plants were in 2010, later on, the plants grew shorter. The measurements of stem length of cut (sawn-off) plant show that the greatest value of cut stem length in 2010 was $2.93 \mathrm{~m}$, in 2011, the biggest stem length was $2.24 \mathrm{~m}$, and in $2012-2.38 \mathrm{~m}$.

The stems of wild nettle were also tall enough, i.e. $1.54 \mathrm{~m}$ (in 2010), but the stems of cultivated nettle were significantly taller. In 2011 , only plants of treatment with lower planting density had significantly taller stems.

Table 6. The length of cut stinging nettle stems (without stubble) and total stem length of all plants per ha at harvesting

Upytė Experimental Station, 2010-2012

\begin{tabular}{|c|c|c|c|c|}
\hline \multirow{2}{*}{ Treatments } & \multicolumn{2}{|c|}{$\begin{array}{l}\text { Length of cut stem } \\
\mathrm{m}\end{array}$} & \multicolumn{2}{|c|}{$\begin{array}{l}\text { Length of cut stems of all plants per ha } \\
\qquad \mathrm{m} \mathrm{ha}^{-1}\end{array}$} \\
\hline & cultivated nettle & $\begin{array}{l}\text { wild and cultivated } \\
\text { nettle }\end{array}$ & cultivated nettle & $\begin{array}{l}\text { wild and cultivated } \\
\text { nettle }\end{array}$ \\
\hline \multicolumn{5}{|c|}{2010} \\
\hline Wild nettle & - & 1.54 & - & 726957 \\
\hline Cultivated nettle, $3^{\text {rd }}$ year, $60 \times 60 \mathrm{~cm}$ & $1.71 *$ & $1.71 *$ & 1555092 & $1555092 *$ \\
\hline Cultivated nettle, $2^{\text {nd }}$ year, $60 \times 60 \mathrm{~cm}$ & 1.89 & $1.89 *$ & 1537633 & $1537633^{*}$ \\
\hline Cultivated nettle, $2^{\text {nd }}$ year, $60 \times 100 \mathrm{~cm}$ & 1.85 & $1.85^{*}$ & 1019954 & 1019954 \\
\hline Average & 1.81 & 1.75 & 1370893 & 1209909 \\
\hline \multicolumn{5}{|c|}{2011} \\
\hline Wild nettle & - & 0.83 & - & 498522 \\
\hline Cultivated nettle, $4^{\text {th }}$ year, $60 \times 60 \mathrm{~cm}$ & 1.00 & 1.00 & 1215720 & 1215720 \\
\hline Cultivated nettle, $3^{\text {rd }}$ year, $60 \times 60 \mathrm{~cm}$ & 1.09 & 1.09 & 1176225 & 1176225 \\
\hline Cultivated nettle, $3^{\text {rd }}$ year, $60 \times 100 \mathrm{~cm}$ & $1.35^{*}$ & $1.35^{*}$ & 1639407 & $1639407^{*}$ \\
\hline Average & 1.14 & 1.07 & 1343784 & 1132468 \\
\hline \multicolumn{5}{|c|}{2012} \\
\hline Wild nettle & - & 1.05 & - & 687400 \\
\hline Cultivated nettle, $5^{\text {th }}$ year, $60 \times 60 \mathrm{~cm}$ & 0.97 & 0.97 & 1166093 & 1166093 \\
\hline Cultivated nettle, $4^{\text {th }}$ year, $60 \times 60 \mathrm{~cm}$ & 0.95 & 0.95 & 1067359 & 1067359 \\
\hline Cultivated nettle, $4^{\text {th }}$ year, $60 \times 100 \mathrm{~cm}$ & 0.9 & 0.9 & 1250545 & 1250545 \\
\hline Average & 0.94 & 0.97 & 1161332 & 1042849 \\
\hline
\end{tabular}

\footnotetext{
* - significant at 0.05 probability level
} 
Nevertheless very high plants were found in 2012, the mean length of cut stems was the lowest over the year of investigation - the value close to 1 meter, and the wild nettle showed longer stems than cultivated nettle. It was interesting to imagine what number of stems in meters could be produced in a stinging nettle crop. It was more than a million meters per hectare for cultivated nettle, and twice or even three times less for wild nettle.

Investigation of stinging nettle in Italy in 20062007 showed that German clones produced stems the height of which was $1.71 \mathrm{~m}$, diameter $-5.2 \mathrm{~mm}$ (Bacci et al., 2007). Dreyer et al. (1996) investigated the growth of six clones of cultivated stinging nettle and found that the length of stems in the first cropping year was 1.41$1.77 \mathrm{~m}$, the diameter $-3.8-4.9 \mathrm{~mm}$. The stem length increased (till $2.0-2.5 \mathrm{~m}$ ) in the $2^{\text {nd }}$ cropping year and slightly decreased (till $2.0-2.3 \mathrm{~m}$ ) in the $3^{\text {rd }}$ cropping year. We noticed similar peculiarities. In 2009, the average length of sawn-off stems was very similar (1.66$1.68 \mathrm{~m}$ ) in all treatments (crop of the $2^{\text {nd }}$ and $1^{\text {st }}$ cropping year). The tallest sawn-off plants reached a height of 2.79-2.81 m (total plant height with the stubble would be $2.94-2.96 \mathrm{~m}$ ) (Jankauskienè, Gruzdevienè, 2010). In 2010 , the height of plants of the $3^{\text {rd }}$ cropping year was also smaller $(1.86 \mathrm{~m})$ than that of the $2^{\text {nd }}$ cropping year $(2.04 \mathrm{~m})$ (Table 7). And later on, the plants produced shorter stems.

In 2010, the cultivated nettle was significantly taller than the wild one. Wild nettle was luxuriant in 2012, and outstripped cultivated nettle in stem height. The stem diameter did not differ significantly between cultivated nettle, but in 2012, luxuriant plants of wild nettle had thicker stems, perhaps this happened because of the lower crop density of wild nettle as it had more favourable conditions for sunlight and nutrients.

Table 7. The height and diameter of stinging nettle stems at harvesting

Upytè Experimental Station, 2010-2012

\begin{tabular}{|c|c|c|c|c|}
\hline \multirow[b]{2}{*}{ Treatments } & \multicolumn{2}{|c|}{ Height $\mathrm{m}$} & \multicolumn{2}{|c|}{ Diameter mm } \\
\hline & cultivated nettle & $\begin{array}{c}\text { wild and cultivated } \\
\text { nettle }\end{array}$ & cultivated nettle & $\begin{array}{c}\text { wild and cultivated } \\
\text { nettle }\end{array}$ \\
\hline \multicolumn{5}{|c|}{2010} \\
\hline Wild nettle & - & 1.69 & - & 4.13 \\
\hline Cultivated nettle, $3^{\text {rd }}$ year, $60 \times 60 \mathrm{~cm}$ & $1.86^{*}$ & $1.86^{*}$ & 3.49 & 3.49 \\
\hline Cultivated nettle, $2^{\text {nd }}$ year, $60 \times 60 \mathrm{~cm}$ & 2.04 & $2.04 *$ & 4.74 & 4.74 \\
\hline Cultivated nettle, $2^{\text {nd }}$ year, $60 \times 100 \mathrm{~cm}$ & 2.00 & $2.00 *$ & 4.38 & 4.38 \\
\hline Average & 1.96 & 1.90 & 4.21 & 4.19 \\
\hline \multicolumn{5}{|c|}{2011} \\
\hline Wild nettle & - & 0.98 & - & 2.67 \\
\hline Cultivated nettle, $4^{\text {th }}$ year, $60 \times 60 \mathrm{~cm}$ & 1.15 & 1.15 & 3.23 & 3.23 \\
\hline Cultivated nettle, $3^{\text {rd }}$ year, $60 \times 60 \mathrm{~cm}$ & 1.24 & 1.24 & 3.27 & $3.27 *$ \\
\hline Cultivated nettle, $3^{\text {rd }}$ year, $60 \times 100 \mathrm{~cm}$ & $1.50 *$ & $1.50 *$ & 3.47 & $3.47 *$ \\
\hline Average & 1.29 & 1.22 & 3.32 & 3.16 \\
\hline \multicolumn{5}{|c|}{2012} \\
\hline Wild nettle & - & 1.20 & - & 3.21 \\
\hline Cultivated nettle, $5^{\text {th }}$ year, $60 \times 60 \mathrm{~cm}$ & 1.12 & 1.12 & 2.69 & $2.69 *$ \\
\hline Cultivated nettle, $4^{\text {th }}$ year, $60 \times 60 \mathrm{~cm}$ & 1.10 & 1.10 & 2.60 & $2.60 *$ \\
\hline Cultivated nettle, $4^{\text {th }}$ year, $60 \times 100 \mathrm{~cm}$ & 1.05 & 1.05 & 2.36 & $2.36^{*}$ \\
\hline Average & 1.09 & 1.12 & 2.55 & 0.271 \\
\hline
\end{tabular}

* - significant at 0.05 probability level

It is likely that with senescence of stinging nettle crop, the productivity of it reduces already from the $3^{\text {rd }}$ $4^{\text {th }}$ cropping year, but further investigation is needed to confirm this.

\section{Conclusions}

1. Over all experimental years, irrespective of the crop age, the per-plant productivity of cultivated stinging nettle (Urtica dioica L.) was higher at a planting density of $60 \times 100 \mathrm{~cm}$. The mean green above-ground mass yield per plant decreased along with crop senescence. The green biomass yield was generally higher in the treatments planted at $60 \times 60 \mathrm{~cm}$ density. The absolutely dry aboveground mass yield of wild nettle was approximately 2-3 times lower than that of cultivated nettle.

2. Plants in older crop produced more shoots in the spring. The mean crop density measured at harvest increased over the experimental years and was higher in older crop. Starting from the $3^{\text {rd }}$ cropping year, crop density at harvest in the treatment planted at lower density $(60 \times 100 \mathrm{~cm})$ was higher than that in the treatments planted at higher density $(60 \times 60 \mathrm{~cm})$. The number of wild nettle stems per $\mathrm{m}^{2}$ was much lower than that of cultivated nettle.

3. The greatest increase (110-217\%) in crop density over the vegetation period was established in the plots planted at lower density $(60 \times 100 \mathrm{~cm})$.

4. Older crop of stinging nettle produced shorter stems.

\section{Acknowledgments}

The research was part of the long-term LRCAF programme "Biopotential and Quality of Plants for Multifunctional Use". 


\section{References}

Bacci L., Baronti S., Crisci A., Predieri A., Virgilio di N., Romani A., Pirelli P. 2007. The cultivation of fibre nettle in Italy: first results. Innovative technologies for comfort: proceedings of the $4^{\text {th }}$ global workshop (general consultation) of the FAO/ESCORENA European cooperative research network on flax and other bast plants. Arad, Romania, p. 249

Bacci L., Baronti S., Predieri S., Virgilio di N. 2009. Fiber yield and quality of fiber nettle (Urtica dioica L.) cultivated in Italy. Industrial Crops and Products, 29 (2-3): 480-484 http://dx.doi.org/10.1016/j.indcrop.2008.09.005

Bacci L., Lonardo di S., Albanese L., Mastriomei G., Perito B. 2010. Effect of different extraction methods on fibre quality of nettle (Urtica dioica L.). Textile Research Journal, 81 (8): 827-837 http://dx.doi.org/10.1177/0040517510391698

Bisht S., Bhandari S., Bisht N. S. 2012. Urtica dioica (L): an undervalued, economically important plant. Agricultural Science Research Journal, 2 (5): 250-252

Bnouham M., Merhfour F.-Z., Ziyyat A., Mekhfi H., Mohammed A., Legssyer A. 2003. Antihyperglycemic activity of the aqueous extract of Urtica dioica. Fitoterapia, 74: $677-681$ http://dx.doi.org/10.1016/S0367-326X(03)00182-5

Buivydaitė V. V., Vaičys M., Juodis J., Motuzas A. 2001. The classification of Lithuania's soils. Vilnius, Lithuania, p. 76 (in Lithuanian)

Camilli F., Bacci L., Grifoni D., Albanese L., Lonardo di S., Pinelli P., Scardigli A., Campo M., Romani A., Verdinelli M., Cossu C. S., Fois X. 2012. Multifunctional plants natural extracts: characterization and innovative poly-use of Urtica dioica L., Daphne gnidium L. and Helichrysum italicum L. XXVI international conference on polyphenols. Firenze, Italy, p. 123-124

Chrubasika J. E., Roufogalisb B. D., Wagnerc H., Chrubasika S. A. 2007. A comprehensive review on nettle effect and efficacy profiles, Part I. Herba urticae. Phytomedicine, 14: 423-435 http://dx.doi.org/10.1016/j.phymed.2007.03.004

Dirsè A., Taparauskienè L. 2010. Humidity fluctuations in plant vegetation periods and a comparison of its assessment methods. Žemès ūkio mokslai, 17 (1-2): 9-17 (in Lithuanian)

Dreyer J., Dreyling G., Feldmann F. 1996. Cultivation of stinging nettle Urtica dioica $\mathrm{L}$. with high fibre content as a raw material for the production of fibre and cellulose: qualitative and quantitative differentiation of ancient clones. Journal of Applied Botany, 70 (1-2): 28-39

Fern K. 1997. Plants for a future. Edible, medicinal and useful plants for a healthier world. England, $344 \mathrm{p}$.

Gulcin I., Kufrevioglu O. I., Oktay M., Buyukokuroglu M. E. 2004. Antioxidant, antimicrobial, antiulcer and analgesic activities of nettle (Urtica dioica L.). Journal of Ethnopharmacology, 90: 205-215 http://dx.doi.org/10.1016/j.jep.2003.09.028

Hara T., Srůtek M. 1995. Shoot growth and mortality patterns of Urtica dioica, a clonal forb. Annals of Botany, 76: $235-243$ http://dx.doi.org/10.1006/anbo.1995.1092

Hartl A., Vogl Ch. R. 2002. Dry matter and fiber yields, and the fiber characteristics of five nettle clones (Urtica dioica L.) organically grown in Austria for potential textile use. American Journal of Alternative Agriculture, 17 (4): 195-200 http://dx.doi.org/10.1079/AJA2002195
Jankauskienė Z., Gruzdevienė E. 2008. Stinging nettle (Urtica dioica L.) - an alternative fibre plant. Opportunities and Challenges of National Economic Development: proceedings of the international conference. Rezekne, Latvia, p. 175-182

Jankauskienė Z., Gruzdevienė E. 2010. Investigation of stinging nettle (Urtica dioica L.) in Lithuania. Latgale National Economy Research, 1 (2): 176-186

Jankauskienė Z., Gruzdevienè E. 2013. Investigation of changes of stinging nettle's (Urtica dioica $\mathrm{L}$.) crop density. Environment. Technology. Resources: proceedings of the $9^{\text {th }}$ international scientific and practical conference, vol. I. Rezekne, Latvia, p. 116-121

Klimešova J. 1994. The effects of timing and duration of floods on growth of young plants of Phalaris arundinacea L. and Urtica dioica L.: an experimental study. Aquatic Botany, 48: 21-29 http://dx.doi.org/10.1016/0304-3770(94)90071-X

Kohler K., Schmidtke K., Rauber R. 1999. Eignung verschiedener Pflanzenarten zur Untersaat in Fasernesseln (Urtica dioica L.). Hoffmann H., Muller S. (eds.). Beitrage Zur 5. Wissenschaftstagung Zum Okologischen Landbau. Berlin, Germany, p. 496-500 (in German)

Nebel K., Kokhan A., Selcuk R., Pichert T. 2002. Textiles from fibre nettles. Production, Processing and Use of Natural Fibres: book of abstracts. Potsdam, Germany, p. 77-78

Schmidtke K., Rauber R., Kohler K. 1998. Ertragsbildung von Fasernsseln (Urtica dioica L.). Mitteilungen der Gesellschaft fur Pflanzenbauwussenschaften, 11: 107-108 (in German)

Tarakanovas P., Raudonius S. 2003. Agronominių tyrimu duomenų statistinè analizè taikant kompiuterines programas ANOVA, STAT, SPLIT-PLOT iš paketo SELEKCIJA ir IRRISTAT. Lithuanian University of Agriculture, $58 \mathrm{p}$. (in Lithuanian)

Tavano D., Gallucci T., Amaggio G., Lagioia G. 2011. Potential of dyeing and fiber plants in Apulia region. Journal of Commodity Science, Technology and Quality, 50 (III): 207-224

Taylor K. 2009. Biological flora of the British Isles: Urtica dioica L. Journal of Ecology, 97: 1436-1458 http://dx.doi.org/10.1111/j.1365-2745.2009.01575.x

Virgilio di N., Predieri S., Gatti E., Bacci L., Baronti S., Romani A., Rossi F. 2008. The stinging nettle (Urtica dioica L.): a neglected, multifunctional species for a lowimpact land use. Italian Journal of Agronomy / Rivista di Agronomia, 3 (3): 443-444

Virgilio di N., Papazoglou E. G., Jankauskiene Z., Lonardo di S., Praczy M., Wielgusz K. 2014. The potential of stinging nettle (Urtica dioica L.) as a crop with multiple uses. Journal of Industrial Crops and Products http://dx.doi.org/10.1016/j.indcrop.2014.08.012

Vogl Ch. R., Hartl A. 2003. Production and processing of organically grown fiber nettle (Urtica dioica L.) and its potential use in the natural textile industry: a review. American Journal of Alternative Agriculture, 18 (3): $119-128$ http://dx.doi.org/10.1079/AJAA200242

Whitney Ph. J., Gibbs G. 2006. The common stinging nettle: resource or risk? Biologist, 53 (4): 176-182 
ISSN 1392-3196 / e-ISSN 2335-8947

Zemdirbyste-Agriculture, vol. 102, No. 1 (2015), p. 31-40

DOI 10.13080/z-a.2015.102.004

\title{
Produktyvumo pokyčiai skirtingo sodinimo tankio ir ivairaus amžiaus didžiosios dilgèlès (Urtica dioica L.) pasẻlyje
}

\author{
Z. Jankauskienè, E. Gruzdevienè
}

Lietuvos agrarinių ir miškų mokslų centro Upytės bandymų stotis

\section{Santrauka}

Pastaruoju metu Europoje didèja susidomejjimas didžiaja dilgèle kaip labai vertingu, turinčiu daugybę panaudojimo sričių (vaistai, maistas, kosmetika, repelentai, trąšos, pluošto gaminiai ir kt.) augalu. Lietuvos agrarinių ir miškų mokslų centro Upytės bandymų stotyje 2010-2012 m. atlikti dilgèlių pasėlio, įrengto sodinant skirtingu tankumu $(60 \times 60$ ir $60 \times 100 \mathrm{~cm})$, tyrimai. Kai kurie kultūrinių dilgèlių tyrimų duomenys lyginti su laukinių dilgèlių duomenimis. Tyrimų duomenimis, nepriklausomai nuo pasèlio naudojimo metų, visais tyrimų metais kultūrinių dilgèlių vieno augalo stiebų skaičius buvo didžiausias $60 \times 100 \mathrm{~cm}$ tankumo pasėlyje. Didžiausias vidutinis žalios antžeminès biomasès derlius buvo gautas laukeliuose, kuriuose dilgèlès sodintos $60 \times 60 \mathrm{~cm}$ atstumu. Augalams senstant vieno sodinto augalo vidutinis žalios antžeminès biomasès derlius mažèjo. Žalios antžeminès biomasès derlius (ir pasėlio tankis) buvo kur kas mažesnis laukinių dilgèlių nei kultūrinių. Senesni augalai (auginti daugiau metų) išaugino daugiau stiebų, bet jie buvo žemesni.

Reikšminiai žodžiai: biomasė, didžioji dilgèlè, stiebų skersmuo, stiebų ilgis, stiebų skaičius. 